\title{
Erratum to: Preliminary fixed-bed downdraft gasification of birch woodchips
}

\author{
S. Sarker $\cdot$ H. K. Nielsen
}

Published online: 4 July 2015

(C) Islamic Azad University (IAU) 2015

Erratum to: Int. J. Environ. Sci. Technol. (2015)

\section{2:2119-2126}

DOI 10.1007/s13762-014-0618-8

The original publication of this article unfortunately contained three minor mistakes.

- In the fourth line of the Abstract " $11.5 \% \mathrm{CO}$ " should be corrected to " $11.8 \% \mathrm{CO}$ ".

- In the second line of sub-section "Gasification of birch wood chips" "(moisture content $15.2 \%)$ " should be corrected to "(moisture content $\sim 7 \%$ )".

- The information in the first row of Table 3 "Proximate analysis (dry basis)" should be corrected to "Proximate analysis".

The online version of the original article can be found under doi:10.1007/s13762-014-0618-8.

S. Sarker $(\varangle) \cdot$ H. K. Nielsen

Faculty of Engineering and Sciences, University of Agder, 4898

Grimstad, Norway

e-mail: shiplu.sarker@uia.no 